\title{
EIF4E wt Allele
}

National Cancer Institute

\section{Source}

National Cancer Institute. ElF4E wt Allele. NCI Thesaurus. Code C105124.

Human EIF4E wild-type allele is located within 4q21-q25 and is approximately $59 \mathrm{~kb}$ in length. This allele, which encodes eukaryotic translation initiation factor 4E protein, plays a role in both mRNA cap recognition and ribosome recruitment. 